\title{
DETERMINASI IKLIM SEKOLAH, MOTIVASI BERPRESTASI, KEBUTUHAN PERALATAN PRAKTEK TERHADAP HASIL BELAJAR PENGOLAHAN DAN PENYAJIAN MAKANAN KONTINENTAL PESERTA DIDIK BOGA KELAS XI DI SMK NEGERI 2 SINGARAJA
}

\author{
Ni Luh Juniasih, Anak Agung Gede Agung, Kadek Rihendra Dantes \\ Program Studi Administrasi Pendidikan, Program Pasca Sarjana \\ Universitas Pendidikan Ganesha \\ Singaraja, Indonesia
}

\author{
e-mail: Ni Luh Juniasih, Anak Agung Gede Agung, Kadek Rihendra \\ Dantes\}@pasca.undiksha.ac.id
}

\begin{abstract}
Abstrak
Pencapain determinasi iklim sekolah, motivasi berprestasi, kebutuhan peralatan praktek terhadap hasil belajar pengolahan dan penyajian makanan kontinental peserta didik boga kelas XI di SMK Negeri 2 Singaraja masih rendah. Oleh sebab itu perlu dilakukannya upaya peningkatan iklim sekolah, motivasi berprestasi, kebutuhan peralatan praktek untuk peningkatan hasil belajar pengolahan dan penyajian makanan kontinental peserta didik boga kelas XI di SMK N 2 Singaraja. Penelitian ini bertujuan untuk mengetahui (1) determinasi iklim sekolah terhadap hasil belajar pengolahan dan penyajian makanan kontinental peserta didik boga kelas XI di SMK N 2 Singaraja, (2) determinasi motivasi berprestasi terhadap hasil belajar pengolahan dan penyajian makanan kontinental peserta didik boga kelas XI di SMK N 2 Singaraja, (3) determinasi kebutuhan peralatan praktek terhadap hasil belajar pengolahan dan penyajian makanan kontinental peserta didik boga kelas XI di SMK N 2 Singaraja, (4) determinasi iklim sekolah, motivasi berprestasi, kebutuhan peralatan praktek terhadap hasil belajar pengolahan dan penyajian makanan kontinental peserta didik boga kelas XI di SMK N 2 Singaraja. Sampel penelitian ini adalah peserta didik kelas XI boga SMK N 2 Singaraja berjumlah 100 orang. Instrumen penelitian ini terdiri dari kuesioner iklim sekolah, kuesioner motivasi berprestasi, kuesioner kebutuhan peralatan praktek dan tes hasil belajar pengolahan dan penyajian makanan kontinental. Hasil penelitian ini menunjukkan bahwa (1) iklim sekolah sebesar 0,02\%, motivasi berprestasi sebesar $0,56 \%$, kebutuhan peralatan praktek sebesar $0,12 \%$ signifikan terhadap hasil belajar pengolahan dan penyajian makanan kontinental sebesar $78,62 \%$.

Kata Kunci: iklim sekolah, motivasi berprestasi, kebutuhan peralatan praktek, hasil belajar
\end{abstract}

\begin{abstract}
Achievement of school climate determination, achievement motivation, practice equipment needs to the learning result of processing and presentation of continental food of culinary learners of class XI at SMK Negeri 2 Singaraja still low. There fore it is necessary to make efforts to improve school climate, achievement motivation, equipment needs of practice to improve learning result of processing and presentation of continental food of culinary learners of class XI at SMK N 2 Singaraja. This study aims to determine (1) determination of school climate on the learning result of processing and presentation of continental food of Xga class culinary learners at SMK N 2 Singaraja, (2) determination of achievement motivation toward result of learning process and presentation of continental food culinary learners class XI in SMK N 2 Singaraja, (3) determination of practice equipment needs to the learning result of processing and presentation of continental food of culinary learners of class XI in SMK N 2 Singaraja, (4) determination of school climate, achievement motivation, practice equipment needs toward learning result of processing and presentation continental food caterer boga class $\mathrm{XI}$ in SMK N 2 Singaraja. The sample of this research is students of class XI boga SMK N 2 Singaraja amounted to 100 people. The instruments of this study consisted of school climate questionnaires, achievement motivation questionnaires, questionnaires of practical equipment needs and test results of processing and presentation of continental food. The results of this study indicate that (1) school climate is $0,022 \%$, achievement motivation equal to $0,575 \%$, requirement of appliance equipments $0,116 \%$ significant to result of study of processing and serving continental food equal to $78,62 \%$.

Keywords: School Climate, Achievement Motivation, Practice Equipment Needs,
\end{abstract}

Results Learning Processing and Serving of Continental Food 


\section{PENDAHULUAN}

Di dalam Undang-Undang Nomor 20 Tahun 2003 (UU20/2003) tentang Sistem pendidikan Nasional (2003:2-3) dinyatakan bahwa pendidikan adalah usaha sadar dan terencana untuk mewujudkan suasana belajar dan proses pembelajaran agar peserta didik secara aktif mengembangkan potensi dirinya untuk memiliki kekuatan spiritual keagamaan , pengendalian diri, kepribadian, kecerdasan, akhlak mulia, serta keterampilan yang diperlukan dirinya, masyarakat, bangsa, dan Negara.

Kualitas pendidikan banyak dikaitkan dengan hasil belajar peserta didik. Hasil belajar merupakan hasil usaha seseorang dalam menempuh suatu proses, yang dalam kehidupan persekolahan diwujudkan dalam suatu nilai yang disebut dengan hasil belajar. Irma (2016) Hasil belajar merupakan sesuatu yang diperoleh peserta didik setelah mengikuti proses belajar mengajar. Di Indonesia terdapat beberapa jenis pendidikan formal untuk tingkat atas yaitu Sekolah Menengah Atas (SMA), Madrasah Aliyah (MA), dan Sekolah Menengah Kejuruan (SMK). Sekolah Menengah Kejuruan (SMK) mengajarkan keterampilan agar dapat mengembangkan diri, memupuk rasa percaya diri peserta didik terhadap kemampuan dirinya untuk menghasilkan peserta didik SMK yang siap terjun dalam masyarakat dan profesional di bidangnya keterampilan dan kemampuan sehingga siap memasuki dunia industri serta siap kerja. SMK Negeri 2 Singaraja merupakan sekolah menengah kejuruan dalam kelompok pariwisata. SMK Negeri 2 Singaraja memiliki program keahlian antara lain akomodasi perhotelan, tata boga, tata kecantikan dan tata busana. Pada program keahlian tata boga di SMK Negeri 2 Singaraja, Mata pelajaran pengolahan dan penyajian makanan kontinental merupakan mata pelajaran program keahlian dalam jurusan tata boga kosentrasi jasa boga di SMK Negeri 2 Singaraja. Mata pelajaran yang mempelajari tentang makanan barat seperti benua Eropa, Amerika, dan Australia serta salah satu mata pelajaran yang wajib diikuti oleh peserta didik.

Mata pelajaran Pengolahan dan penyajian makanan kontinental secara umum memiliki tujuan yaitu peserta didik dapat memiliki skill atau kompetensi pada setiap kompetensi dasar yang diberikan dalam lingkup mata pelajaran makanan pengolahan dan penyajian makanan continental, maka dari itu hasil belajar dalam mata pelajaran pengolahan dan penyajian makanan kontinental, berpengaruh terhadap hasil lulusan peserta didik yang berkompten di dalam bidang tata boga. Belajar menunjukkan adanya perubahan yang sifatnya positif, sehingga pada tahap akhir akan didapat keterampilan, kacakapan dan pengetahuan baru. Hasil dari proses belajar tersebut tercemin dalam hasil belajarnya, namun dalam upaya meraih hasil belajar yang memuaskan dibutuhkan proses belajar dan menguasai materi yang telah diberikan.

Upaya untuk meningkatkan mutu pendidikan tidak bisa dilepaskan dari faktor pendukung. Mutu pendidikan akan sangat terkait dengan hasil belajar peserta didik. Pencapaian hasil belajar dipengaruhi oleh faktor yang mempengaruhi peserta didik. Dari berbagai penelitian yang dilakukan usaha untuk meningkatkan hasil belajar peserta didik akan sangat dipengaruhi faktor-faktor baik secara ekternal dan faktor internal. Banyaknya faktor eksternal dan internal yang telah disampaikan sebelumnya dalam upaya peningkatan hasil belajar peserta didik yang berujung pada hasil belajar peserta didik penulis melihat ada faktorfaktor yang paling berperan dalam meningkatkan mutu pendidikan dalam upaya meningkatkan hasil belajar peserta didik. Iklim sekolah adalah suasana dalam organisasi sekolah yang diciptakan oleh pola hubungan antar pribadi yang berlaku (Depdikbud, 1982).

Pola hubungan antar pribadi tersebut dapat meliputi hubungan antara guru dengan murid, antara murid dengan murid, antara guru dengan guru dan antara guru dengan pimpinan sekolah. Iklim sekolah yang kondusif dapat dilihat dari keakraban, persaingan, ketertiban organisasi sekolah, keamanan dan fasilitas sekolah. pola hubungan yang kondusif itu akan mengembangkan potensi-potensi diri peserta didik secara terarah sehingga pada akhirnya mereka merasa puas dalam belajar. Semakin baik pola hubungan antar pribadi yang terjadi di lingkungan sekolah diduga juga akan menyebabkan semakin tingginya hasil belajar peserta didik.

Faktor internal yang juga sangat berpengaruh terhadap hasil belajar adalah motivasi untuk berprestasi, Dwijandono (2004) mengatakan bahwa masalah besar bagi guru dan 
peserta didik dikelas adalah motivasi, motivasi yang paling penting dalam psikologi pendidikan adalah motivasi berprestasi, dimana seseorang berjuang untuk mencapai sukses atau memilih suatu kegiatan yang berorientasi untuk tujuan sukses. Guru-guru berharap supaya setiap peserta didik menggunakan seluruh potensi dan waktunya selama disekolah, sehingga tujuan belajar tercapai secara maksimum. Motivasi adalah suatu dorongan untuk berprestasi dari seseorang baik yang datang dari dalam dirinya maupun dari luar. Peserta didik yang memiliki prestasi lebih tinggi cenderung akan berhasil dalam bidang tertentu.

Tinggi rendahnya hasil belajar peserta didik dipengaruhi oleh faktor-faktor yang saling berkaitan dan saling mempengaruhi antar satu dengan yang lainnya. Faktor eksternal sangat berpengaruh dalam proses belajar mengajar untuk mencapai hasil belajar yang diinginkan oleh seluruh warga sekolah terutama peserta didik dimana dalam faktor ekternal pada pelajaran atau pun praktek pengolahan dan penyajian makanan kontinental disebutkan kelengkapan peralatan praktek menjadi pengaruh besar dalam meunculkan motivasi berprestasi dan hasil belajar yang ditentukan oleh sekolah atau peserta didik.

Sekolah kejuruan mempunyai fungsi untuk mengarahkan dan mengalokasikan generasi muda yang dididiknya ke berbagai karier atau pekerjaan yang menanti di masyarakat. Pendidikan kejuruan merupakan upaya menyediakan stimulus berupa pengalaman belajar dan interaksi dengan dunia luar untuk membantu anak didik mengembangkan diri dan potensinya. Lebih lanjut dijelaskan oleh Slamet,(1990: 19) bahwa tujuan pendidikan sekolah kejuruan adalah membimbing peserta didik agar menjadi individu yang mampu berpikir mandiri serta mengambil keputusan, memiliki harga diri dan mencintai profesi, berjiwa sosial serta memiliki pandangan bebas dan demokratis mengenai negara, menjunjung tinggi moral dan agama. Menengah Kejuruan (SMK) adalah sebuah sekolah kejuruan yang bertujuan mencetak tenaga-tenaga yang terampil dan siap terjun ke dunia kerja. Di tengah kebijakan pemerintah untuk meningkatkan jumlah SMK, persoalan mutu pendidikan di jenjang SMK masih menghadapi masalah. Pendidikan berfokus untuk menyiapkan tenaga kerja terampil di tingkat menengah ini justru menghadapi kendala dalam penyediaan peralatan praktik kerja. Sekitar 55 persen peralatan praktik di SMK kondisinya berada di bawah standar sarana nasional. Sarana dan prasarana yang lengkap serta memenuhi standar kompetensi dunia industri merupakan salah satu kebutuhan utama bagi sekolah kejuruan. Hal ini karena sarana dan prasarana yang lengkap dan sesuai standar akan membantu peserta didik dalam upaya peningkatan keterampilan dan keahlian sesuai dengan bidang atau jurusannya masingmasing. Sebaliknya, kurangnya sarana dan prasarana pendukung, langsung maupun tidak langsung akan menghambat proses belajar mengajar dan peningkatan keahlian peserta didik.

Berdasarkan deskripsi yang sudah dijelaskan diatas maka dalam penelitian ini memutuskan untuk mengambil judul mengenai "Determinasi Iklim Sekolah, Motivasi Berprestasi, Kebutuhan Peralatan Praktek Terhadap Hasil Belajar Pengolahan dan Penyajian Makanan Kontinental Peserta Didik Boga Kelas XI di SMK Negeri 2 Singaraja.

\section{METODE PENELITIAN}

Penelitian ini dilaksanakan pada Sekolah Menengah Kejuruan (SMK) Negeri 2 Singaraja di jalan Srikandi No. 9 Singaraja. Penelitian ini dilaksanakan selama dua bulan dari bulan Pebruari sampai dengan bulan April. Rancangan penelitian yang digunakan dalam penelitian kuantitatif dengan pendekatan pada subjek penelitian yang dilakukan ini tergolaong penelitian "ex post facto" dalam pelaksanaannya tidak ada perlakuan terhadap variabel, karena kondisi variabel yang diteliti sudah tampak atau sudah berlangsung. Dalam menganalisis data digunakan regresi linear dimana penelitian ini melibatkan 4 variabel terdiri dari satu variabel terikat yaitu hasil belajar pengolahan dan penyajian makanan kontinental $(Y)$ dengan tiga variabel bebas yaitu variabel bebas yang paling pertama ikli sekolah $\left(X_{1}\right)$, variabel bebas yang kedua motivasi berprestasi $\left(\mathrm{X}_{2}\right)$, variabel bebas yang ketiga adalah kebutuhan peralatan praktek $\left(\mathrm{X}_{3}\right)$.

Agung (2004:69) Populasi adalah keseluruhan objek dalam suatu penelitian. Menurut Sugiono (2008:117) populasi ialah wilayah generalisasi yang terdiri atas objek/subjek yang mempunyai kualitas dan karakteristik tertentu ditetapkan oleh peneliti untuk dipelajari dan kemudian ditarik kesimpulannya. 
Populasi dalam penelitian ini adalah seluruh peserta didik boga kelas XI di SMK N 2 Singaraja. Jumlah peserta didik boga di SMK N 2 Singaraja adalah sebanyak 198 orang.

Jika dari keseluruhan populasi yang ada, kemudian hanya diambil sebagian menjadi wakil dari populasi tersebut, maka wakil populasi tersebut dinamakan sampel. Jadi, sampel merupakan bagian dari populasi yang secara langsung dikenai penelitian. (Agung, 2015), sedangkan menurut Sukardi (2003:54) sampel adalah sebagian dari jumlah populasi yang dipilih untuk sumber data. Hal ini juga dinyatakan oleh Sugiono (2008: 118) menyatakan bahwa sampel adalah bagian dari jumlah dan karakteristik yang dimiliki oleh populasi. Jadi dapat disimpulkan bahwa sampel merupakan bagian dari seluruh populasi yang dijadikan objek penelitian.Teknik yang digunakan dalam pengambilan sampel ini disebut sebagai teknik sampling. Dalam penelitian ini teknik sampling yang digunakan adalah simplerandom sampling. Teknik ini dilakukan dengan mengambil secara acak sederhana langsung pada individu populasi yang tersedia. Untuk menentukan jumlah sampel yang akan diteliti makan akan berpedoman pada table morgan. Di karenakan populasi penelitian ini terlalu banyak, maka seluruh populasi digunakan sebagai sampel penelitian dalam penelitian ini yakni berjumlah 100 orang peserta didik.

Pengumpulan data adalah suatu proses pengadaan data primer untuk keperluan penelitian yang digunakan untuk menguji hipotesis yang telah dirumuskan. Untuk memperoleh data mengenai variabel yang diteliti dalam penelitian ini data dikumpulkan dengan kuesioner mengenai hasil belajar, iklim sekolah, motivasi berprestasi, kebutuhan peralatan praktek. Untuk memperoleh data tersebut digunakan 4 buah instrument, yaitu: 1) hasil belajar terdiri dari kuesioner sikap, tes kemampuan, dan kuesioner keterampilan 2) kuesioner iklim sekolah 3) kuesioner motivasi berprestasi, 4) kuesioner kebutuhan peralatan praktek.

Alat pengumpul data harus memenuhi persyaratan yaitu syarat validitas dan reliabilitas dalam mengungkap apa yang hendak diukur. Ada dua persyaratan yang hendak digunakan dalam pengumpulan data penelitian yaitu validitas dan reliabilitas (Hamzah, 2007:63). Validitas instrumen dalam penelitian ini meliputi dua segi yaitu validitas isi dan validitas butir. Validitas isi dibantu oleh dua orang ahli/ expert, kemudian dianalisis dengan teknik Gregory.

Sebelum instrumen digunakan, maka perlu diuji dahulu validitas dari masing-masing pertanyaan yang ada sebagai alat pengambilan data. Dengan demikian terlebih dahulu diadakan uji coba terhadap kuisioner kemudian hasil uji coba ini dianalisis. Untuk menguji validitas butir rumus yang digunakan adalah rumus kontribusi product moment dari Pearson (Arikunto, 1995).

Pengujian terhadap reabilitas instrumen dilakukan melalui pendekatan ketetapan internal. Uji reliabilitas adalah ketepatan dan keajegan alat pengukur tersebut dalam menilai apa yang diinginkan, artinya kapanpun alat tersebut digunakan akan diperoleh hasil yang sama (Puger, 2004). Pengujian reliabilitas dengan rumus Alpha dari Crombach (Arikunto, 1997:164).

Informasi yang dicari dalam penelitian ini adalah: 1) iklim sekolah, motivasi berprestasi, kebutuhan peralatan praktek, serta gambaran umum hasil belajar pengolah dan penyajian makanan continental peserta didik kelas XI Tata Boga di SMK Negeri 2 Singaraja. Gambaran umum tersebut berupa skor rata-rata, simpangan baku, skor terendah, skor tertinggi, modus, dan median, 2) model regresi antara empat variabel bebas dan satu variabel terikat baik sendiri-sendiri maupun bersama-sama, 3) koefisien regresi dari masing-masing model regresi, digunakan untuk meramal atau menaksir besarnya variansi nilai $Y$ (variabel terikat), dan 4) korelasi parsial digunakan untuk menentukan hubungan murni antara satu variabel bebas dengan variabel terikat, dengan mengendalikan variabel bebas lainnya.

Kegiatan analisis data terdiri atas kegiatan pengolahan data dan analisis statistik. Kegiatan analisis data meliputi: 1) menyunting data secara manual. Penyuntingan dilakukan karena kemungkinan ada data yang tidak jelas, atau kesalahan dalam pengisian instrument, sehingga tidak memenuhi syarat untuk dianalisis, 2) mentabulasi data, dan 3) mengolah data dalam bentuk sesuai kebutuhan.

Untuk menguji hipotesis yang telah dirumuskan, terlebih dahulu dilakukan analisis data yang telah dikumpulkan. Dalam melakukan analisis data untuk penelitian ini dilakukan dengan 
tiga tahapan yakni: 1) tahap deskripsi data, 2) tahap pengujian persyarat analisis, 3) tahap pengujian hipotesis.

Data yang telah diperoleh dari penelitian dideskripsikan menurut masing-masing variabel. Oleh tujuannya seperti itu, maka akan dicari harga rerata (M), standar deviasi (SD), modus (Mo), dan median (Me) setiap variabel yang diteliti.

Setelah data dideskripsikan, maka analisis dilanjutkan dengan menggunakan teknik regresi sederhana, regresi ganda, dan korelasi varsial. Persyaratan yang berkaitan dengan teknik analisis data tersebut harus dibuktikan secara statistik.

Setelah seluruh uji prasyarat terpenuhi, maka dilanjutkan dengan uji hipotesis. Untuk menguji hipotesis pertama, kedua, ketiga dan keempat dalam penelitian ini digunakan teknik analisis korelasi sederhana (korelasi product moment pearson). Sedangkan untuk menguji hipotesis ke empat, digunakan teknik analisis korelasi ganda, regresi ganda, dan korelasi parsial. Untuk menganalisis uji hipotesis dalam penelitian ini digunakan program SPSS-17.00 for windows.

\section{HASIL PENELITIAN DAN PEMBAHASAN}

1. Menguji Hipotesis Determinasi Iklim Sekolah $\left(X_{1}\right)$ terhadap Hasil Belajar Pengolahan dan Penyajian Makanan Kontinental Peserta Didik Boga di SMK N 2 Singaraja ( $Y$ ).

Berdasarkan hasil analisis kolerasi parsial didapat nilai kolerasi $\left(r_{1 y-23}\right)$ sebesar 0,148 dan signifikasi sebesar 1,771. Dengan menggunakan taraf signifikansi $0,05(0,02<0,05)$, maka hipotesis nihil yang berbunyi tidak terdapat determinasi yang signifikan antara iklim sekolah terhadap hasil belajar pengolahan dan penyajian makanan kontinental peserta didik boga kelas XI SMK N 2 Singaraja di tolak. Dengan demikian ditarik kesimpulan bahwa terdapat determinasi yang signifikan antara iklim sekolah terhadap hasil belajar pengolahan dan penyajian makanan kontinental peserta didik boga kelas XI SMK N 2 Singaraja.. Besaran determinasi iklim sekolah terhadap hasil belajar pengolahan dan penyajian makanan kontinental peserta didik boga kelas XI SMK N 2 Singaraja adalah sebesar $22 \%$.

Temuan penelitian ini sejalan Bachria Ratna Dewi dan Alsa Asmadi (2015). Meneliti tentang iklim sekolah dan dukungan social guru matematika sebagai prediktor keberhasilan prestasi belajar matematika siswa SMA Dalam penelitian ini menyatakan bahwa tujuan dari penelitian ini adalah untuk memprediksi prestasi belajar matematika siswa Sekolah Menengah Atas (SMA) berdasarkan pada iklim sekolah dan dukungan sosial guru matematika. Penelitian ini menggunakan pendekatan kuantitatif dengan desain korelasional untuk menguji iklim sekolah dan dukungan sosial guru matematika sebagai prediktor keberhasilan prestasi belajar matematika siswa SMA. Analisis data yang digunakan adalah analisis regresi berganda. Subjek penelitian merupakan siswa kelas XI jurusan IPA berjumlah 88 siswa. Penelitian ini dilakukan di salah satu SMA Negeri di Yogyakarta. Alat ukur yang digunakan adalah skala iklim sekolah dan skala dukungan sosial guru matematika serta nilai murni UAS matematika kelas XI IPA. Hasil uji hipotesis menunjukkan bahwa iklim sekolah dan dukungan sosial guru matematika baik bersama maupun parsial tidak dapat memprediksi prestasi belajar matematika siswa SMA atau dengan kata lain hipotesis dalam penelitian ini ditolak, maka dapat disimpulkan bahwa iklim sekolah memberikan determinasi yang signifikan terhadap hasil belajar pengolahan dan penyajian makanan kontinental siswa boga kelas XI di SMK Negeri 2 Singaraja.

\section{Menguji Hipotesis Determinasi Motivasi Berprestasi $\left(X_{2}\right)$ terhadap Hasil Belajar Pengolahan dan Penyajian Makanan Kontinental Peserta Didik Boga di SMK N 2 Singaraja (Y).}

Berdasarkan hasil analisis kolerasi parsial didapat nilai kolerasi $\left(r_{2 y-23}\right)$ sebesar 0,331 dan signifikasi sebesar 1,580. Dengan menggunakan taraf signifikansi 0,05 $(0,02<0,05)$, maka hipotesis nihil yang berbunyi tidak terdapat determinasi yang signifikan antara motivasi berprestasi terhadap hasil belajar pengolahan dan penyajian makanan kontinental peserta didik boga kelas XI SMK N 2 Singaraja di tolak. Dengan demikian ditarik kesimpulan bahwa terdapat determinasi yang signifikan antara motivasi berprestasi terhadap hasil belajar 
pengolahan dan penyajian makanan kontinental peserta didik boga kelas XI SMK $\mathrm{N} 2$ Singaraja. Besaran determinasi motivasi berprestasi terhadap hasil belajar pengolahan dan penyajian makanan kontinental peserta didik boga kelas XI SMK N 2 Singaraja adalah sebesar $5,75 \%$.

Temuan penelitian ini sejalan Karel muskana (2015) meneliti tentang analisis motivasi berprestasi atlet pusat pendidikan dan latihan olahraga pelajar provinsi nusa tenggara timur. Dalam penelitian ini dinyatakan bawah hubungan dan pengaruh faktor intrinsik dan faktor ekstrinsik terhadap motivasi berprestasi atlet. Penelitian ini dilakukan melalui metode sensus dengan pendekatan kuantitatif, kualitatif, dan gabungan menggunakan teknik dan analisis data korelatif kuantitatif untuk skala interval dan analisis korelatif kuantitatif untuk skala ordinal menggunakan Spearman Rank. Populasi dalam penelitian ini berjumlah 36 atlet, dengan variabel penelitian terdiri dari enam variabel bebas yang tergolong dalam faktor intrinsik (kompetensi atlet, pemenuhan kebutuhan, status dan tang-gung jawab) dan faktor ekstrinsik (lingkungan, teknik supervisi, dan jaminan karir). Hasil yang diperoleh melalui uji statis- tik korelatif kuantitatif menunjukkan bahwa masing-masing parameter (kompetensi atlet, pemenuhan kebutuhan, status dan tanggung jawab, lingkungan, teknik supervisi, dan jaminan karir) mempunyai hubungan yang signifikan dan relevan dengan teori serta berpengaruh secara parsial dan simultan terhadap motivasi berprestasi atlet. Hasil analisis koefisien determinasi (R2) menunjukkan bahwa sumbangan atau kontribusi dari aspek-aspek pada variabel internal dan eksternal terhadap motivasi berprestasi atlet mempunyai kontribusi yang signifikan pada motivasi berprestasi atlet PPLP NTT, maka dapat disimpulkan bahwa motivasi berprestasi memberikan determinasi yang signifikan terhadap hasil belajar pengolahan dan penyajian makanan kontinental siswa boga kelas XI di SMK Negeri 2 Singaraja.

\section{Menguji Hipotesis Determinasi Kebutuhan Peralatan Praktek $\left(\mathrm{X}_{3}\right)$ terhadap Hasil Belajar Pengolahan dan Penyajian Makanan Kontinental Peserta Didik Boga di SMK N 2 Singaraja (Y).}

Berdasarkan hasil analisis kolerasi parsial didapat nilai kolerasi $\left(r_{3 y-23}\right)$ sebesar 0,013 dan signifikasi sebesar 1,079. Dengan menggunakan taraf signifikansi 0,05 $(0,02<0,05)$, maka hipotesis nihil yang berbunyi tidak terdapat determinasi yang signifikan antara motivasi berprestasi terhadap hasil belajar pengolahan dan penyajian makanan kontinental peserta didik boga kelas XI SMK N 2 Singaraja di tolak. Dengan demikian ditarik kesimpulan bahwa terdapat determinasi yang signifikan antara kebutuhan peralatan praktek terhadap hasil belajar pengolahan dan penyajian makanan kontinental peserta didik boga kelas XI SMK $\mathrm{N} 2$ Singaraja. Besaran determinasi motivasi berprestasi terhadap hasil belajar pengolahan dan penyajian makanan kontinental peserta didik boga kelas XI SMK N 2 Singaraja adalah sebesar $1,16 \%$.

Temuan penelitian ini sejalan Willy Artha Wirawan (2015). Meneliti tentang analisis kebutuhan perlengkapan bengkel otomotif sesuai persyaratan standar BSNP. Dalam penelitian ini dinyatakan bawah penelitian ini dilaksanakan dengan tujuan untuk mengetahui tingkat kelengkapan bengkel otomotif SMK Negeri di Kota Malang. Penelitian ini menggunakan rancangan penelitian survey deskriptif dengan pendekatan kuantitatif. Peneliti menggunakan teknik observasi checklist, wawancara tidak terstruktur dan dokumentasi dalam pengumpulan data dan dianalisis dengan statistik deskriptif. Populasi dalam penelitian ini terdiri dari SMK Negeri di Kota Malang yang mempunyai laboratorium bengkel otomotif yang baik menurut data Dinas Pendidikan Kota Malang yaitu terdiri dari tiga SMK Negeri yang dipilih dan diambil sebagai sampel. Berdasarkan penelitian dan analisis data secara keseluruhan simpulan hasil penelitian sebagai berikut. (1) Tingkat kelengkapan peralatan bengkel di SMK Negeri kota Malang masuk dalam kategori lengkap (69\%). (2) tingkat kesesuaian area kerja di SMK Negeri Kota Malang masuk dalam kategori cukup lengkap (47\%). Yang telah mengarah berdasarkan Badan Standar Nasional Pendidikan dalam Permendiknas No. 40 tahun 2008, maka dapat disimpulkan bahwa motivasi berprestasi memberikan determinasi yang signifikan 
terhadap hasil belajar pengolahan dan penyajian makanan kontinental siswa boga kelas XI di SMK Negeri 2 Singaraja.

\section{Menguji Hipotesis Determinasi Iklim Sekolah $\left(\mathbf{X}_{1}\right)$, Motivasi Berprestasi $\left(\mathbf{X}_{2}\right)$, Peralatan Praktek $\left(\mathrm{X}_{3}\right)$ terhadap Hasil Belajar Pengolahan dan Penyajian Makanan Kontinental Peserta Didik Boga di SMK N 2 Singaraja (Y)}

Hasil diatas menunjukkan koefision korelasi ganda $\mathrm{R}$ 0.592. koefisien tersebut signifikan karena setelah Diuji dengan F-tes diperoleh harga F sebesar 17.310 dengan signifikansi 0.00 . Dengan demikian hipotesis nol $\left(\mathrm{H}_{0}\right)$ yang menyatakan "Secara bersama-sama, tidak terdapat determinasi yang signifikan antara iklim sekolah, motivasi berprestasi, dan kebutuhan peralatan praktek terhadap hasil belajar pengolahan dan penyajian makanan kontinental siswa boga kelas XI di SMK Negeri 2 Singaraja" ditolak. Hal ini berarti hipotesis penelitian (Ha) yang diajukan, yaitu "Secara bersama-sama, terdapat determinasi yang signifikan antara iklim sekolah, motivasi berprestasi, dan kebutuhan peralatan praktek terhadap hasil belajar pengolahan dan penyajian makanan kontinental siswa boga kelas XI di SMK Negeri 2 Singaraja. Berdasarkan paparan diatas, tampak jelas bahwa dengan bahwa dengan iklim sekolah yang tinggi maka hasil belajar dapat dioptimalkan. Dengan demikian dugaan yang menyatakan bahwa iklim sekolah, motivasi berprestasi, kebutuhan peralatan praktek memberikan determinasi yang signifikan terhadap hasil belajar pengolahan dan penyajian makanan kontinental.

\section{PENUTUP}

Berdasarkan hasil penelitian dan pembahasan yang telah dilakukan, maka dapat ditarik kesimpulan sebagai berikut.

1. Hasil penelitian ini menunjukkan bahwa iklim sekolah berdeterminasi secara signifikan terhadap terhadap Hasil Belajar Pengolahan dan Penyajian Makanan Kontinental. Ini artinya bahwa implikasinya adalah perlu peningkatan kondisi iklim sekolah agar semakin kondusif. Untuk meningkatkan terhadap Hasil Belajar Pengolahan dan Penyajian Makanan Kontinental diciptakan lingkungan fisik yang nyaman, seperti sekolah atau ruang kelas yang perlu ditata dengan baik, fasilitas perlu dilingkapi, kebersihan ruang kelas perlu ditingkatkan serta mengefektifkan hubungan antara peserta didik dengan prinsip saling percaya.

2. Hasil penelitian ini menunjukkna bahwa motivasi berprestasi berdeterminasi terhadap hasil belajar pengolahan dan penyajian makanan kontinental . oleh karena itu, peserta didik perlu diberikan motivasi, baik. Selain itu. Juga perlu diberikan perlakuan yang wajar dan adil sesuai dengan hak, martabat dan kewajibannya serta memberikan peluang dalam mengembangkan prestasinya.

3. Hasil penelitian ini menunjukkan bahwa kebutuhan peralatan praktek berdeterminasi terhadap hasil belajar pengolahan dan penyajian makanan kontinental. Ini artinya kelengkapan peralatan praktek disiap praktek harus disediakan sesuai dengan keperluannya sehingga kegiatan dalam belajar mengajar praktek berjalan dengan rencana yang sudah disiapkan, dan peserta didik pun dengan semangat mengikuti kegiatan pembelajar sehingga meningkatkan hasil belajar.

Saran yang dapat diajukan pada penelitian ini adalah sebagai berikut.

Siswa seharusnya dapat meningkatkan iklim sekolah dan motivasi berprestasinya agar dapat meningkatkan hasil belajar mereka.

Guru hendaknya mampu untuk memperhatikan peserta didik dalam pengembangan serta tingkah laku yang dimiliki oleh peserta didik. Hal ini bertujuan agar proses pembelajaran yang ada di sekolah dapat berjalan dan dikelola secara optimal, sehingga dapat berkontribusi positif terhadap hasil belajar siswa.

Telah ditemukannya bahwa kebutuhan peralatan praktek sangat menentukan peningkatan hasil belajar peserta didik. Karena kebutuhan peralatan dalam praktek sangat penting menunjang proses belajar mengajar dan meningkatkan mutu pendidikan. Oleh karena itu Kepala Sekolah, agar dapat meningkatkan penyediaan peralatan yang lengkap bagi peserta 
didik, sehingga secara bersama-sama meningkatkan hasil belajar dan mutu pendidikan di SMK Negeri 2 Singaraja.

Peneliti lain diharapkan mampu mengembangkan variabel lain dalam usaha meningkatkan hasil belajar pengolahan dan penyajian makanan kontinental, sehingga dapat mengembangkan ilmu pengetahuan ke arah yang lebih baik.

\section{DAFTAR RUJUKAN}

Agung, A. A. G. 2014. Metodologi Penelitian Pendidikan. Malang: Aditya Media Publising.

Agung, A. A. G. 2015. Statistikan Inferensial (Disertasi Aplikasi SPSS). Singaraja:Undiksha

Arikunto,S. 2006. Prosedur Penelitian Suatu Pendekatan Praktik.Jakarta: Rineka Cipta.

Depdiknas. 2008. Kurikulum Tingkat Satuan Pendidikan. Jakarta: Dikmenum Depdiknas.

Hamzah B. Uno.2006. Teori Motivasi dan Pengukurannya Analisis Di Bidang Pendidikan. Jakarta: Bumi Aksara.

Slamet. 1990. Pondasi Pendidikan Kejuruan. Lembaran Perkuliahan. Yogyakarta: Pascasarjana IKIP Yogyakarta.

Sugiyono. 2010. Metode Penelitian Kuantitatif Kualitatif \& RND. Bandung: Alfabeta.

Takarin, Elly, dkk. 2012. Mengolah Makanan Kontinental. Bandung: Acarya Media Utama.

Winardi, J. 2004. Motivasi dan Pemotivasian dalam Manajemen. Jakarta: Raja Grafindo Persada.

Wirawan, Willy Artha, 2015. "Analisis Kebutuhan Perlengkapan Bengkel Otomotif Sesuai Persyaratan Standar BNSP". No 2, (hlm.2). 